\title{
"This is why students feel lost when they go into teaching practice": English Language Teachers' Views on their Initial Teacher Education
}

\author{
Sue Garton \\ Aston University, Birmingham, UK \\ https://orcid.org/0000-0002-7421-0858
}

\begin{abstract}
The last 20-25 years have seen a significant shift in the views about what teachers need to know to be able to teach. This shift has led to new developments in the theory of second language teacher education (SLTE) and a growth in research in this area. One area of research concerns the attitudes and expectations of those learning to become teachers. While most studies in this area focus on teacher education programmes in BANA countries, this article looks at data from student teachers studying in Russia and Uzbekistan. The study employed a quantitative and qualitative research design, using a researcher-designed on-line questionnaire. Through snowball sampling, data from 161 students and recent graduates in the two countries were collected, analysed, and compared to investigate the content of SLTE programmes. The study identified what the novice teachers felt were the strengths and weaknesses of their programme, and what changes they would like to see. Results showed that while the respondents were mainly satisfied with their methodology, and theoretical linguistics courses, they felt the need for more practice, both teaching and language practice. The data also revealed that, in Uzbekistan in particular, the idea of global English struggles to take hold as native-speaker models remain the norm. The implications of the study underline the need for SLTE to explicitly link theory to practice and to promote the idea of varieties of English, rather than focus on native-speaker norms.
\end{abstract}

Keywords: language teacher education; Russia; Uzbekistan

\section{Introduction}

The rapid spread of English as a global language in the last 25-30 years has been accompanied by the reform of school language curricula away from grammarfocused teaching towards the development of communicative competence. Numerous studies have focused on the issues that such a shift has raised, and especially the challenges for language teachers (see, for example, Copland, Garton \& Burns, 2014). Graves and Garton (2017) note that there is often a gap between the principles of communicative curriculum reform and actual classroom practice, and identify both ideological and practical reasons for the gap. These reasons 
include socio-cultural appropriacy, clashes with teachers' beliefs and experience, large classes, lack of appropriate materials, and the impact of national examinations. However, perhaps the biggest obstacle to the successful implementation of curriculum reform is the lack of teacher training (Rahman \& Pandian, 2018) or provision of training that does not facilitate a real understanding of new methods of teaching (Hardman \& A-Rahman, 2014).

At the same time, changes have taken place in second language teacher education (SLTE) with a shift in views around three fundamental questions (Johnson, 2016): what do teachers need to know? What do teachers need to be able to do? How best can they learn? In particular, there has been a move away from the idea of teacher education as a set of prescribed behaviours to be followed to teacher learning as social practice (Freeman, 2020; Johnson, 2016)

These two interlinked phenomena have led to a rich and diverse field of research in SLTE with studies on, for example, teacher identity, reflection, and observation and feedback, to name just a few (see Walsh \& Mann, 2019, for a comprehensive overview of research into English language teacher education). Another area is that of the attitudes and expectations of novice teachers ${ }^{i}$ concerning their training programme, and their perceptions of its effectiveness.

As Johnson (2016) notes, the spread of English and the increased demand for English teachers has led to ever greater numbers seeking teacher education in socalled BANA countries (Britain, Australasia, and North America) (Holliday 1994). However, this mobility has given rise to concerns about the extent to which teacher education programmes prepare novice teachers for the contexts in which they teach (see, for example, Barnawi \& Le Ha, 2015). As Johnson (2016, p.130) asserts,

"understanding the extent to which the language learning settings in which language teacher education takes place adequately prepares language teachers for any and all instructional contexts is an underresearched yet highly relevant emerging area of debate."

Johnson appears to be mainly concerned with how SLTE in BANA countries prepares teachers to teach when they return to their local contexts, and to date, the majority of studies on the attitudes of novice teachers concerns those studying in BANA countries (see, for example, Copland et al., 2017; Faez \& Valeo, 2012). Far fewer studies have examined the attitudes and expectations of novice teachers who have studied locally. Moreover, the few existing studies are concentrated on a limited number of countries such as Turkey (see, for example, Akcan, 2015) and Spain (Martínez Agudo, 2017) Yet, in the context of widespread curriculum reform and the ever-increasing demand for English teachers in public state school systems, it would seem important to research whether SLTE programmes in a variety of contexts outside BANA countries prepare language teachers adequately.

This article, therefore, focuses on teachers from two countries of the ex-Soviet Union whose SLTE programmes have not so far been widely studied: Russian and 
Uzbekistan. Part of a larger project aimed at strengthening language teacher training programmes in these countriesii, the article presents data from 161 students and graduates to investigate the content of their training programmes. The research questions guiding the study were:

1. What do novice teachers perceive as the strengths of their SLTE programme?

2. What do novice teachers perceive as the weaknesses of their SLTE programme?

3. How can SLTE programmes better prepare teachers for the language classroom?

\section{Literature review}

Formal programmes in higher education institutions are still the main form of language teacher education (SLTE) around the world and maintain an important "professional gate-keeping function" (Wright, 2010, p.262), determining who will teach, particularly in state education systems.

Richards (2008) identifies two issues that he maintains shape SLTE. The first is the development of the knowledge base of teaching and our understanding of what teachers need to know. Freeman (2020) identifies two problems associated with this knowledge base: one is how theory becomes practice and the second is who defines what is valued as knowledge, what Freeman calls 'positionality'. For the most part, practices in BANA countries have defined SLTE (Freeman, 2020).

The second issue identified by Richards (2008) is the external pressures brought about by globalisation and the spread of English as the international language. This spread has led ministries to formulate new national policies for language curricula and language teacher education. As the role of English changes in the world, so too does what the knowledge base needs to address, particularly concerning what is taught and who is teaching (Freeman, 2020).

Traditionally, SLTE has been grounded in linguistics and applied linguistics with a clear separation between the theoretical knowledge gained in classes in the institution and the application of that knowledge during a practicum (Wright, 2010). This was a one-size-fits-all model, based on the assumption that general theories could be translated into practice whatever the context (Johnson 2016).

It was in the 1990s that the view of language teacher education began to change (see Wright, 2010, for a detailed overview). The publication of Freeman and Johnson's (1998) reconceptualisation of SLTE marked a paradigm shift from a behaviourist, knowledge transmission view of teacher education to a constructivist approach, which considers the nature of teacher learning. SLTE was viewed as "a dialogic process of co-constructing knowledge that is situated in and merges out of participation in particular socio-cultural practices and contexts." (Johnson, 2016, p.122)

Despite the shift in the nature of SLTE and the academic debates around it, there remain doubts about the impact that these developments have had on actual teacher education programmes and whether teachers are equipped for the realities of the classroom (Farrell, 2015). 
Hennissen, Beckers and Moerkerke (2017) cite several studies from different disciplines showing the difficulties that pre-service teachers have in making the connections between the theory they have learned on their courses, and the demands of the practicum, including difficulties in linking their own beliefs and ideas about teaching to the practicum. Whilst not specifically about SLTE, Hennissen et al.'s (2017) study implies that teacher education programmes are still not taking a constructivist approach. They conclude:

"Pre-service teachers apply theory, as offered in curriculum courses at the teacher education institute, only to a limited degree in educational practice. Theory is part of teacher education, but it is not embedded in teaching practice and not anchored in the actions of pre-service teachers.[...] pre-service teachers receive information they cannot transfer, because they lack relevant experiences. This is a feed-forward problem." (Hennissen et al., 2017, p.314)

Within SLTE many programmes include what are considered to be practical courses, such as methodology, but they are often 'knowledge about' methodology, rather than 'knowledge how' to teach (Richards, 2008). Such theoretical approaches can leave teachers unsure as to how to bridge the gap from the course to the classroom. This was the case, for example, with the Malaysian primary school teachers in Hardman and A-Rahman's (2014) study. The teachers were aware of suitable activities for children, such as songs and games, but they did not know how to use such activities in a language classroom. Even more recently, studies such as Yin (2019) are still finding limitations in how SLTE prepares teachers for the reality of the classroom. Yin researched pre-service teachers in Korea as they tried to apply what they had learned in their theoretical courses to their practice during the practicum. Her results showed that, while the trainees felt that they were prepared in the classroom skills that they needed, they were not ready to deal with the realities of the classroom. A similar result was noted in Vietnam by Canh (2014) who found that, during the practicum, student teachers tended to imitate their cooperating teacher rather than trying to apply or adapt what they had learned on their programme. Canh (2014) concluded that student teachers were not prepared for the transition from their programme to the realities of the classroom.

These studies were concerned mainly with the practicum and novice teachers' experiences and practices. A related area of research focuses on novice teachers' views about their formal preparation and in particular what they see as the strengths and weaknesses of their programmes and how to improve their learning experiences.

A number of studies in this area have been carried out in BANA countries. Copland et al.'s (2017) study, for example, found that the most popular courses for TESOL master's students in the UK were Methodology, Second Language Acquisition, and Teaching Practice. Li and Tin (2013, cited in Copland et al., 2017, p. 9) looked at the general perceptions of students on a Master's programme in TESOL in New Zealand. Their participants identified several strengths of their programme, including applied linguistics knowledge, opportunities for reflection, and the realisation that learning to teach is an on-going process. The 
weaknesses they found were a lack of teaching practice and the fact that the programme did not consider the socio-cultural context to which the students would be returning. Focusing on a different type of programme and context, Faez and Valeo's (2012) participants were enrolled in a Canadian TESOL certificate programme preparing teachers to teach ESOL in Canada. The trainee teachers in this programme found the practicum to be the most useful aspect and suggested that it should increase in duration. Least useful were the theoretical elements (SLA and theoretical linguistics), mainly because theory was not linked to practice.

A more limited number of studies have been carried out on SLTE in non-English speaking countries. One exception is Turkey, where three studies found similar results (Akcan, 2015; Coskun \& Daloglu, 2010; Seferoğlu, 2006). Similar to Li and Tin (2013, cited in Copland et al., 2017), the trainee teachers in Coskun and Daloglu's (2010) study saw the theoretical aspects of their programme as a strength. However, they also lamented the lack of opportunities for practice, both in courses on the programme and during the practicum. The lack of connection between theory and practice was also identified by participants in Seferoğlu's (2006) study. Whilst the trainee teachers were generally positive towards the methodology courses, they perceived a lack of opportunity to implement theory, and they called for more micro-teaching and opportunities to practice. Akcan's (2015) participants were generally positive about their programme and, like the trainees in Faez and Valeo (2012), they saw the practical teaching experience as a strength, but they also expressed the need for more practice. They stated that there was too much theory and not enough practice on the programme. They put forward several suggestions for improvement, including specific areas of classroom practice such as more on classroom management, and dealing with learning disabilities, behavioural problems, and lack of motivation in learners; better language improvement courses; use of videos of real classrooms; participation in exchange programmes such as Erasmus; participation in on-line fora to interact with teachers from other countries.

In a different context and with slightly different results, Martínez Agudo (2017) looked at TESOL education in Spain. Generally, the participants in this study were satisfied with the teaching skills, pedagogical knowledge, and practice they obtained, and they felt prepared to teach. The biggest weakness was the lack of emphasis on English proficiency, and participants felt there was a lack of balance among linguistic, pedagogical, and managerial competences. They called for more specialist subjects related to English as well as for opportunities to teach abroad and to interact with native speakers. As with the other studies mentioned above, overall satisfaction with the practical aspects of the programme did not exclude calls for more practice and less theory. Lack of consideration of context was another common theme.

Despite the numerous calls for context-appropriate approaches and methodology, together with calls to move away from native-speaker norms, SLTE still seems to struggle to adapt to such needs. In a number of the studies cited above, student teachers refer to the context-appropriacy of their TESOL programmes. Various studies have noted the lack of fit between BANA-based teacher education and 
local realities when teachers return home (see, for example, Chowdhury, 2003; Barnawi \& Le Ha, 2015). This possible mismatch raises the question as to whether teacher education outside BANA countries better reflects the local context.

So far this article has given an overview of developments in the theory and principles of SLTE. It has also presented a summary of key findings in previous research on the attitudes and expectations of student teachers on programmes in both BANA and non-BANA contexts. In the next section, the current situation in Russia and Uzbekistan is briefly outlined.

\section{Teacher education in the Russian Federation and Uzbekistan}

Teacher education in the countries of the Ex-Soviet Union was generally characterised by teacher-centred approaches, at least until the 1990s. Aydarova (2014) notes that until that time, in Russia, how language teacher knowledge was conceptualised was indicative of a view of the 'teacher as knowledge producer' in which teachers were also seen as subject specialists and scientists.

In the early 2000s, Russia signed the Bologna Declaration, leading to reforms in the higher education system and teacher education. Whilst the Bologna Process is not explicitly concerned with teacher education, its principles are in line with the constructivist views of SLTE outlined in the previous section. The most recent curriculum plan for language teacher education at the Bachelor level in Russia dates back to 2011 and is based on a 4-year programme. In an analysis of the effects on the Bologna Process on teacher education in Russia, Aydarova (2014) outlines some criticisms of the most recent plan. These include an increase in the number of independent study hours, seen as problematic "due to a lack of material provision for independent work and an absence of a culture of individual responsibility" (Aydarova, 2014, p. 71). The number of electives, well over half the subjects, is also seen as an issue leading to a lack of consistency in the knowledge base that teachers have.

Uzbekistan did not sign the Bologna declaration, but it does adhere to many of its principles in formulating its educational reforms. As in Russia, initial teacher education consists of a 4-year bachelor's degree. In 2013, a new bachelor's curriculum, developed by a partnership between the Ministry of Education, the British Council and the Norwich Institute for Language Education, was introducediii. The purpose of the reform was to improve both the pedagogical practice and the English language proficiency of teachers (see, for example, Gulyamova, Irgasheva \& Bolitho, 2014; Isamukhamedova, 2016, for detailed descriptions of the new curriculum and a comparison with the old one).

Independent research into the outcomes of this reform is not yet available. However, anecdotal evidence suggests that it may not have been as successful in bridging the theory-practice gap as hoped and, similar to reform attempts in other countries, the new ideas and approaches may not be widely finding their way into EFL classrooms. Hasanova and Shadieva (2008) note the highly bureaucratised system in Uzbekistan, together with the lack of resources as challenges faced by both schools and higher education institutions. Although Hasanova and Shadieva 
(2008) were writing before the most recent reform, it would seem some of the obstacles remain, and Isamukhamedova (2016) notes there were considerable limitations on what aspects of the degree programme could be changed.

\section{Methodology}

As mentioned in the introduction, this study is part of a larger project. The part of the study reported in this article uses both quantitative and qualitative data, but is primarily a qualitative study situated within a social-constructivist paradigm (Cresswell \& Poth, 2016). The study used a researcher-designed on-line questionnaire to ascertain perceptions of the content of SLTE programmes in Russia and Uzbekistan, together with the attitudes and opinions of those who have experienced them. The survey was provided electronically through Survey Monkey. It combined open and closed questions and was distributed through local project partners using snowball sampling (Taherdoost, 2016). Thus, whilst the survey was initially distributed amongst students and graduates from the participating institutions, they were also asked to distribute amongst their wider networks to obtain a broader view.

The survey items drew on the literature on survey design (see, for example, Dörnyei \& Taguchi, 2009) and were constructed in close collaboration with local partners to ensure greater local relevance. The survey was distributed in English, but project partners advised on phrasing and appropriate expression to ensure mutual understanding as far as possible. Even so, it cannot be discounted that words such as 'practicum' or 'teaching practice' may have been interpreted differently by different respondents. Questions focused on four different areas relating to:

1. demographics (gender, country/place of work, language(s) spoken;

2. qualifications and experience (qualifications obtained, years of experience, languages taught, experiences overseas);

3. content of the training course (modules, the practicum);

4. opinions of the training course (strengths, weaknesses, proposed changes).

These were not separate sections in the questionnaire, but rather questions were given in order of importance of the information for the study on the assumption that response rates would drop off towards the end of the survey. For example, country, place of work, and questions concerning the content of the programme and the respondents' opinions were the first questions, while questions on gender and experience came at the end.

A range of closed and open-ended items was used to gain both quantitative and qualitative responses. The introduction to the questionnaire explained the purpose and that all responses were anonymous. No personal details were collected and researcher contact details were given if participants had any questions or wanted further information. The final data set includes 115 responses from Uzbekistan and 46 from Russia.

The closed questions are presented as raw numbers and percentages to show general trends. The open questions were coded and categorised to identify the 
main themes, and themes are included in the discussion where there are at least five responses from one of the countries. The analysis was also carried out by country to investigate where there were notable differences, enabling comparisons to be made. Given the snowball sampling and the different number of responses from each country, the study does not aim at generalisability. Rather, it intends to give a snapshot of SLTE in particular settings at a particular time.

\section{Findings}

This section presents the key findings from both the closed and open questions. It starts with a brief overview of the experience of the respondents and the subjects that are offered in their programmes. The majority of the section then focuses on the responses to the open questions about the successful aspects of the programmes, what was missing, and what the respondents would change. For each question, the data are presented first in tables showing the main themes together with the numbers and percentages of responses. The tables are followed by examples from the data which add explanatory power to the numerical elements. The examples are reproduced exactly as they were written by the respondents. The numbers in the tables do not correspond to the overall numbers of responses as many responses contained more than one theme, while other responses were unique.

The majority of questionnaire respondents in both countries were already working, with just $19 \%$ saying that they were not currently teaching. Of those who were working, $70 \%$ had between one and five years' experience. This means that most participants had some understanding of how relevant their programme was to actual classrooms.

To ascertain the content of current teacher training provision, a list of 17 common subjects was given for respondents to say which were covered in their programmes. The wording of the question (which of the following areas do you/did you cover on your teacher training courses?) was designed to avoid words such as 'module' or 'course', which may have different meanings in different contexts. Therefore, the answers do not give any indication as to whether the subject was a whole course, just a few classes, or even one class. There were 44 responses from Russia and 96 from Uzbekistan for this question.

Of the 17 subject areas, seven were common to more than $50 \%$ of the respondents in both countries (see Table 1 - percentages are rounded to the nearest whole number.). Language teaching pedagogy/methodology was the most common with over $90 \%$ in both countries saying it was part of their course. Teaching practice and Psychology were also relatively common to both countries. However, there are notable differences amongst the other areas.

Table 1. Courses covered in the programmes

\begin{tabular}{|l|l|l|l|l|}
\hline \multicolumn{1}{|c|}{ Country } & \multicolumn{2}{|c|}{ RF } & \multicolumn{2}{c|}{ Uz } \\
\hline & $\mathrm{N}=$ & $\%$ & $\mathrm{~N}=$ & $\%$ \\
\hline $\begin{array}{l}\text { Language Teaching } \\
\text { Pedagogy/ methods }\end{array}$ & 41 & $93 \%$ & 87 & $91 \%$ \\
\hline Teaching practice & 35 & $80 \%$ & 62 & $65 \%$ \\
\hline
\end{tabular}




\begin{tabular}{|l|l|l|l|l|}
\hline Psychology & 33 & $75 \%$ & 64 & $67 \%$ \\
\hline Linguistics & 36 & $82 \%$ & 53 & $55 \%$ \\
\hline Literature & 31 & $70 \%$ & 52 & $54 \%$ \\
\hline Culture & 27 & $61 \%$ & 50 & $52 \%$ \\
\hline Second language acquisition & 22 & $50 \%$ & 52 & $54 \%$ \\
\hline & 33 & $75 \%$ & 44 & $46 \%$ \\
\hline $\begin{array}{l}\text { Government standards/ } \\
\text { requirements }\end{array}$ & 24 & $55 \%$ & 41 & $43 \%$ \\
\hline Materials & 23 & $52 \%$ & 36 & $38 \%$ \\
\hline $\begin{array}{l}\text { Knowledge about the target } \\
\text { language }\end{array}$ & 22 & $50 \%$ & 19 & $20 \%$ \\
\hline Special educational needs & 22 & $50 \%$ & 27 & $28 \%$ \\
\hline Motivation & & \multicolumn{3}{|l}{} \\
\hline
\end{tabular}

While a total of 12 subject areas were common to more than half the Russian respondents, that number was only seven for Uzbekistan. Moreover, the percentages in the latter were relatively lower. This result would seem to imply that there is more consistency across teacher training programmes in Russia. Given Aydarova's (2014) observations that Russian teacher education is traditionally highly regimented and based on continuity, coherence, and systematicity, it may be that there is more consistency in the knowledge-base of Russian language teachers in the recent reforms of SLTE than Aydarova (ibid) believed. However, the numbers are far from implying a standardised experience. More difficult to interpret is the apparent variety in coverage in programmes in Uzbekistan. It may be that there is a greater number of electives on the programmes or that the curriculum is not being implemented consistently. Further research is needed here, but there would appear to be a certain fragmentation in the knowledge base of novice teachers in both contexts.

Interestingly, there were two subject areas that no course covered: classroom management or learner strategies. These gaps could be an indication that the very practical aspects of language teaching are lacking (see below).

There were 78 responses from Uzbekistan 34 responses from Russia to the open question about what was felt to be the most successful aspects of the programme. Answers were varied but covered four main themes (see Table 2):

1. Methodology, both in general and specific aspects of teaching

2. Learning the language or about the language

3. Theoretical educational courses/topics

4. Theoretical linguistics courses/topics

Table 2. The most successful aspects of programmes

\begin{tabular}{|l|l|l|l|l|}
\hline Theme/country & \multicolumn{2}{|c|}{$\mathrm{Ru}$} & \multicolumn{3}{c|}{$\mathrm{Uz}$} \\
\hline & $\mathrm{N}=$ & $\%$ & $\mathrm{~N}=$ & $\%$ \\
\hline Methodology & 21 & $62 \%$ & 45 & $58 \%$ \\
\hline The language & 7 & $21 \%$ & 28 & $38 \%$ \\
\hline $\begin{array}{l}\text { Theory - } \\
\text { education }\end{array}$ & 7 & $21 \%$ & 16 & $21 \%$ \\
\hline $\begin{array}{l}\text { Theory - } \\
\text { linguistics }\end{array}$ & 4 & $12 \%$ & 13 & $17 \%$ \\
\hline
\end{tabular}


Methodology, or methods of teaching, was by far the most common answer in both countries, with $58 \%$ of the Uzbek respondents and $62 \%$ of the Russian respondents listing this aspect as most successful. Whilst most answers did not give details, simply writing 'methods' or 'methodology', some were more specific, for example:

New approach (student-centred, skill-oriented) (Uz)

Content based learning, language teaching methodology (Uz)

Lesson plans, teaching skills, usage of different types of assessment (Ru)

New technologies, planning lessons, teaching speaking (Ru)

The second most common theme was learning the language or learning about the language, although this was more of a strength for the Uzbek teachers (38\%). In particular, they listed learning about different aspects of language such as grammar, lexis, and phonetics, as well as opportunities to practise.

Knowledge about the target language (Ru)

Study of vocabulary, lexis grammar $(\mathrm{Uz})$

English practice (Uz)

Theoretical linguistics courses, such as lexicography and stylistics, and what might be called theoretical educational courses, such as psychology and pedagogy were also mentioned. However, the numbers were much smaller (between 12\% and $21 \%)$.

The question concerning what was missing from the programme elicited 30 responses from Russia and 78 from Uzbekistan. There was a wide range of very specific answers, the majority of which could loosely be grouped around four themes, but with different responses from each country (Table 3)

1. Language practice

2. Aspects of methodology

3. Education content

4. Linguistic content

Table 3. Elements missing from the programme

\begin{tabular}{|c|c|c|c|c|}
\hline Theme/country & \multicolumn{2}{|c|}{$\mathrm{Ru}$} & $\mathrm{Uz}$ & \\
\hline & $\mathrm{N}=$ & $\%$ & $\mathrm{~N}=$ & $\%$ \\
\hline Language & 4 & $13 \%$ & 32 & $41 \%$ \\
\hline Methodology & 13 & $43 \%$ & 14 & $18 \%$ \\
\hline Education & 4 & $13 \%$ & 5 & $8 \%$ \\
\hline Linguistics & 1 & $3 \%$ & 7 & $9 \%$ \\
\hline
\end{tabular}

While methodology was given as one of the successful aspects, it also figured strongly in what was missing from programmes. In particular, respondents picked out specific aspects of how to teach that they did not learn. For example:

Some modern approaches and methods should be added to teacher training courses such as learner-centred teaching. (Uz)

Material design sessions and assessment (Uz)

How to deal with groups of students with mixed abilities (Ru)

Learning to use the whiteboard and corresponding software (Ru) 
One Uzbek respondent felt that the focus of methodology on the course was too narrow:

Some training programmes are based only on the principles of the communicative approach in language teaching $(\mathrm{Uz})$

These answers would seem to indicate that programmes may be giving students a good overview of methods and approaches to language teaching, but they are lacking in the more practical, classroom-based aspects of teaching. It would also seem that teacher training programmes outside the BANA countries are adopting western approaches.

Respondents identified a number of content areas that were lacking. Seven Uzbek respondents wanted more theoretical courses, with the history of language, lexicography, and stylistics all mentioned. Intercultural communication, teaching young learners, and special education needs were the more educational content courses requested.

By far the most common missing element in Uzbekistan concerned language practice, which was identified by 32 of the 78 respondents, with 16 using the word 'communication' in their reply. Answers concerned communication in general as well as different aspects of language proficiency, especially speaking. For example:

communication (speaking) (listening) (Uz)

oral speech practice $(U z)$

Moreover, 13 of the answers specified that the language practice should be with native speakers:

Communication with native speakers $(\mathrm{Uz})$

Live talks with Englishmen (sic) was missing from the programme (Uz)

Connected to this, both Russian and Uzbek respondents felt that the involvement of native speakers and international experts was missing from their training experiences:

Training by other (international) specialists who can share their

experience; more lessons with native speakers (Uz)

observation of a teaching/learning process in a target language country

(Ru)

Finally, respondents were asked what they would change in their teacher training programme if they had the opportunity, with 72 responses from Uzbekistan and 35 from Russia. To an extent, the responses mirrored what was identified as missing from the programme. However, there were important differences, and there was also a more limited range of answers, which would seem to indicate a clear set of priorities for these novice teachers. The majority of responses from both countries can be categorised into four main themes (Table 4):

1. Internationalisation

2. Methodology

3. Teaching practice

4. Language practice 
Table 4. What is missing from programmes

\begin{tabular}{|l|l|l|l|l|}
\hline Theme/Country & \multicolumn{2}{|c|}{$\mathrm{Ru}$} & \multicolumn{2}{c|}{$\mathrm{Uz}$} \\
\hline & $\mathrm{N}=$ & $\%$ & $\mathrm{~N}=$ & $\%$ \\
\hline Internationalisation & 5 & 14 & 21 & 29 \\
\hline Methodology & 4 & 11 & 19 & 26 \\
\hline Teaching practice & 13 & 31 & 7 & 10 \\
\hline Language practice & 3 & 9 & 14 & 19 \\
\hline
\end{tabular}

What might be termed 'Internationalisation' covered different aspects. These included international exchange programmes, visits/practice overseas, as well as more communication and exchanges with native speakers or international experts. Some typical comments included:

Add more classes with a native speaker professional in the field of TEFL

(Ru)

I would send teachers to the country whose language they are teaching, to practise $(\mathrm{Uz})$

I would add the opportunity of participation in international programms

(Ru)

Practice with native speakers $(U z)$

Generally, the Russian responses focused more on in-country initiatives, while there was a greater call to be able to go overseas from the Uzbek teachers. This may be because Uzbekistan is currently undertaking an extensive programme of overseas training for its language teachers, and so this is a more realistic possibility than perhaps it is for the Russian teachers.

The second area was around methodology and a more practical approach to teacher education. Some teachers made quite general comments about the methodology aspect of their programme and what they would like to change. For example:

Not enough attention was given to methodology - this is why students feel lost when they go into teaching practice (Uz)

I would try to raise training participants' awareness about different approaches in language teaching (Uz)

Add more practice oriented subjects $(R u)$

However, some respondents also identified very specific areas of English language teaching as needed, most of which are very practical, and classroombased. For example:

Learning how to use more English in English lessons (Ru)

Teaching by the help of multimedia would be more interesting and useful (Uz)

Add more specific topics such as assessment, target language, time management and content-based learning. (Uz)

Overall, the data raise potentially interesting issues around teaching practice and the practicum. Only three replies from Uzbekistan and five from Russia indicated this aspect as successful on their programme, and even fewer indicated it as something that was missing (just one from Russia and one from Uzbekistan). 
More responses indicated it as an aspect that teachers would like to change, but these are still fewer than may have been expected, given the findings of previous research outlined above. Comments included:

Pay more attention to the school practice $(\mathrm{Ru})$

More practice at schools less theory $(R u)$

I would give more time to teaching practice and specialist subjects $(U z)$

The final area that respondents would like to change concerns language practice, especially speaking practice. Russian respondents called for more hours of English in general, while the Uzbek teachers also identified the aspects they wanted to improve, especially speaking and listening.

spend more time on the language practice $(\mathrm{Ru})$

more speaking and listening $(\mathrm{Uz})$

Make much hours of speaking clubs (Uz)

One slight caveat here is that it was not always possible to distinguish whether 'practice' referred to teaching practice or language practice. However, there were enough specific calls for more of each to conclude that these are both areas where change is desired.

\section{Discussion and Implications}

Perhaps unsurprisingly, methodology figured strongly in all aspects of this study. It was seen as a strength of the programmes, but there were relatively frequent calls for both more on methods of teaching and more practical approaches to it. Various specific practical areas such as techniques for teaching young learners, using technology, or managing classes were identified. These results are in line with previous studies (see, for example, Coskun \& Daloglu, 2010; Faez \& Valeo, 2012; Martínez Agudo, 2017; Seferoğlu, 2006) and it would seem that, from a student's point of view, programmes and courses can never be too practical. However, the theoretical underpinnings of practice are an important part of the knowledge base of teaching, and, while theoretical courses were seen as a strength of the programmes by some respondents (see also Li \& Tin, 2013, cited in Copland et al., 2017), it seems likely that they fail to make the links to practice. As one Russian participant put it:

Too much theory and not enough exercises or sample tasks which can help teach according to this theory. (Ru)

Teaching practice and the practicum, whilst mentioned by respondents particularly as something to change, were nevertheless given less importance than in previous studies (Akhan, 2015; Faez \& Valeo, 2012). While there were calls for more school-based practice, this was not among the most commonly identified areas, nor was teaching practice seen as a strength or as something that was missing from the programmes. These data are difficult to interpret without further research, but one explanation could be that participants see school-based teaching practice as something separate from their institutional programmes and therefore not within the scope of the questions. If this is the case, then it indicates a significant disconnect between formal classes and the practicum. 
Like the Spanish respondents in Martínez Agudo's (2017) study, Uzbek respondents, in particular, were concerned with language proficiency and opportunities to develop their language skills. The current study also found a strong desire for contact with native speakers and experience overseas, which is similar to Faez and Valeo's (2012) findings and implies that native speaker competence is still seen as the benchmark, even in these days of English as a Lingua Franca. This reflects Cameron and Galloway's (2019) assertion that, despite the recognition in academic circles that English classrooms need to reflect multilingual norms and how English functions globally, a bias towards native speaker norms is still strong in TESOL.

The results of the study have several practical implications for SLTE, which formed the basis of the response of the project in which this study was embedded.

(1) Methodology and specialist courses should have a sound theoretical basis, but the theory needs to be explicitly linked to practice. The project prepared a series of very practical content coursesiv based on the idea of loop input (Woodward, 2003). Novice teachers, therefore, experienced first-hand the type of learner-centred teaching, as well as the specific strategies and techniques that they could use in their own teaching.

(2) To address concerns about language proficiency, and increase opportunities to use the target, as well as increase practical input, the principles of content and language integrated learning (CLIL) (Coyle, Hood \& Marsh, 2010) can be used in language preparation courses. The project prepared an English language improvement course based on CLIL principles with the dual aim of improving both English proficiency and practical teaching skills. This means that all the content of the course is related to the SLTE programme, so that, for example, all reading and listening texts were on topics related to language teaching.

(3) Novice teachers need to be exposed to the idea of English as a Lingua Franca and the acceptance of varieties of English outside so-called native-speaker varieties to relieve the pressure of achieving the often-unattainable goal of native-like proficiency. In the project, debates around varieties of English and ELF, as well as research into language acquisition, were introduced in the Methodology and Age Appropriate Pedagogy courses. Students were presented with the arguments against both the feasibility and desirability of native-speaker norms in ELF contexts and the value of their own experiences as proficient speakers of English was promoted to build confidence.

(4) Opportunities for practical adaptation/implementation of theories, and reflection on them, need to be built into all aspects of teacher training, through, for example, the use of creative assessments. Whilst making changes to the practicum or teaching practice was beyond the remit of the project, opportunities for practical applications were built in to all the new courses. These took the form of, for example, preparing lesson plans or designing materials with a specific theoretical rationale, designing and evaluating uses of software, and so on.

(5) The content of SLTE programmes needs to reflect the realities of classroom teaching and educational cultures of the local context and not unquestioningly follow models imported from BANA countries. All materials in the project 
were prepared by teams of teacher trainers from the three project partner countries (including Ukraine) to ensure that all materials were appropriate to the local context in both content and approach. The final results can be described as a balance between transmission and constructivist approaches which is more appropriate to the contexts for which they were prepared.

\section{Conclusion}

This article has investigated the content of initial teacher training programmes in Russia and Uzbekistan, and has identified some trends that merit further research There are, however, a number of limitations to the research reported here. First of all, the data are only from two countries and the number of participants is relatively small. Moreover, snowball sampling was used, so findings cannot be generalised. It would be useful to carry out much larger-scale quantitative studies to generalise findings. The research instrument used also has its limitations. Although the open questions allow the teachers' voices to be heard to an extent, interviews would have enabled a deeper and more detailed understanding of the issues. Interviews would also have allowed for clarification of unclear or ambiguous responses. Finally, this study did not collect data from teacher educators. Such data would be useful to enable comparisons between the perceptions of the novice teachers, and those of their teacher educators.

Whilst it may be the case that no programme can ever be too practical from a novice teacher's perspective, it is also important not to sacrifice theory to practice. Ultimately, sound theoretical underpinnings will give teachers the knowledge base they need to make informed decisions during their careers. Training programmes, therefore, need to focus on bridging the gap between theory and practice, whilst managing trainee teachers' expectations. Although SLTE has been moving in this direction, at least in principle, for over 20 years, it seems there is still some way to go.

\section{References}

Akcan, S. (2015). Novice non-native English teachers' reflections on their teacher education programmes and their first years of teaching. PROFILE, 18(1), 55-70. https:// doi.org/10.15446/profile.v18n1.48608

Aydarova, O. (2014). Universal principles transform national priorities: Bologna Process and Russian teacher education. Teaching and Teacher Education, 37, 64-75. https://doi.org/10.1016/j.tate.2013.10.001

Barnawi, O., \& Le Ha, P. (2015). From western TESOL classrooms to home practice: a case study with two 'privileged' Saudi teachers. Critical Studies in Education, 56(2), 259276. https://doi.org/10.1080/17508487.2014.951949

Cameron, A., \& Galloway, N. (2019). Local thoughts on global ideas: pre- and in-service TESOL practitioners' attitudes to the pedagogical implications of the globalization of English. RELC JournaL, 50(1), 149-163. https://doi.org/10.1177/0033688218822853

Canh, L. V. (2014). Great expectations: The TESOL practicum as a professional learning experience. TESOL Journal, 5(2), 199-224. https://doi.org/10.1002/tesj.103

Cresswell, J. W., \& Poth, C. N. (2016). Qualitative inquiry and research design: Choosing among five approaches. Thousand Oaks, CA: Sage. 
Chowdhury, M. R. (2003). International TESOL training and EFL contexts: The cultural disillusionment factor. Australian Journal of Education, 47(3), 283-302. https://doi.org/10.1177/000494410304700307

Copland, F., Garton, S., \& Burns, A. (2014). Challenges in teaching English to young learners: Global perspectives and local realities. TESOL Quarterly, 48(4), 738-762. https:// doi.org/10.1002/tesq.148

Copland, F., Viana, V., Bowker, D., Moran, E., Papageorgiou, I., \& Shapira, M. (2017). ELT master's courses in the UK: students' expectations and experiences. ELT Research Papers, 17.04. London: British Council.

Coskun, A., \& Daloglu, A. (2010). Evaluating an English language teacher education program through Peacock's model. Australian Journal of Teacher Education, 35(6), 24-42. https:// doi.org/10.14221/ajte.2010v35n6.2

Coyle, D., Hood, P., \& Marsh, D. (2010). Content and language integrated learning. Cambridge: Cambridge University Press.

Dörnyei, Z., \& Taguchi, T. (2009). Questionnaires in second language research: Construction, administration, and processing. New York, NY: Routledge. https://doi.org/10.4324/9780203864739

Faez, F., \& Valeo, A. (2012). TESOL teacher education: novice teachers' perceptions of their preparedness and efficacy in the classroom. TESOL Quarterly, 46(3), 450-471. https://doi.org/10.1002/tesq.37

Farrell, T. S. (2015). Second language teacher education: A reality check. In T. S. Farrell (Ed.), International perspectives on English language teacher education (pp. 1-15). London: Palgrave Macmillan. https://doi.org/10.1057/9781137440068_1

Freeman, D. (2020). Arguing for a knowledge-base in language teacher education, then (1998) and now (2018). Language Teaching Research,24(1), 5-16. https://doi.org/10.1177/1362168818777534

Freeman, D., \& Johnson, K. E. (1998). Reconceptualizing the knowledge-base of language teacher education. TESOL Quarterly, 32(3), 397-417. https://doi.org/10.2307/3588114

Gulyamova, J., Irgasheva, S., \& Bolitho, R. (2014). Professional development through curriculum reform: the Uzbekistan experience. In D. Hayes (Ed.), Innovations in continuing professional development of English language teachers (pp. 45-62). London: British Council.

Graves, K., \& Garton, S. (2017). An analysis of three curriculum approaches to teaching English in public-sector schools. Language Teaching, 50(4), 441482. https://doi.org/10.1017/s0261444817000155

Hardman, J., \& Rahman, N. A. (2014). Teachers and the implementation of a new English curriculum in Malaysia. Language, Culture and Curriculum, 27(3), 260-277. https://doi.org/10.1080/07908318.2014.980826

Hasanova, D., \& Shadieva T. (2008). Implementing communicative language teaching in Uzbekistan. TESOL Quarterly, 42(1), 138-143. https://doi.org/10.1002/j.15457249.2008.tb00215.x

Hennissen, P., Beckers, H., \& Moerkerke, G. (2017). Linking practice to theory in teacher education: A growth in cognitive structures. Teaching and Teacher Education, 63, 314-325. https://doi.org/10.1016/j.tate.2017.01.008

Holliday, A. (1994). Appropriate methodology and social context. Cambridge: Cambridge University Press.

Isamukhamedova, N. (2016). Curriculum for preparing teachers of English in Uzbekistan: now and then. Humanising Language Teaching, 18(6). https://old.hltmag.co.uk/dec16/mart02.htm 
Johnson, K. E. (2016). Language teacher education. In G. Hall (Ed.), The Routledge handbook of English language teaching (pp. 139-152). London: Routledge. https://doi.org/10.4324/9781315676203

Martínez Agudo, J. (2017). What EFL student teachers think about their professional preparation: Evaluation of an English language teacher education programme in Spain. Australian Journal of Teacher Education, 42(8), 62-76. https://doi.org/10.14221/ajte.2017v42n8.5

Rahman, M. M., \& Pandian, A. (2018). A critical investigation of English language teaching in Bangladesh: Unfulfilled expectations after two decades of communicative language teaching. English Today, 34(3), 43-49. https://doi.org/10.1017/s026607841700061x

Richards, J. (2008). Second language teacher education today. RELC Journal, 39(2), 158-177. https:// doi.org/10.1177/0033688208092182

Seferoğlu, G. (2006). Teacher candidates' reflections on some components of a pre-service English teacher education programme in Turkey. Journal for Education in Teaching, 32(4), 369-378. https:// doi.org/10.1080/02607470600981953

Taherdoost, H. (2016). Sampling methods in research methodology; how to choose a sampling technique for research. International Journal of Academic Research in Management, 5(2), 18-27. https://doi.org/10.2139/ssrn.3205035

Walsh, S., \& Mann, S. (Eds.). (2019). The Routledge handbook of English language teacher education. London: Routledge. https://doi.org/10.4324/9781315659824

Woodward, T. (2003). Key concepts in ELT: Loop input. ELT Journal, 57(3), 301-304. https://doi.org/10.1093/elt/57.3.301

Wright, T. (2010). Second language teacher education: Review of recent research on practice. Language Teaching, 259-296. https://doi.org/10.1017/S0261444810000030

Yin, J. (2019). Connecting theory and practice in teacher education: English-as-a-foreignlanguage pre-service teachers' perceptions of practicum experience. Innovation and Education, 1(4), 1-8. https://doi.org/10.1186/s42862-019-0003-z

This project has been funded with support from the European Commission. This publication reflects the views only of the author, and the Commission cannot be held responsible for any use which may be made of the information contained therein.

iNovice teacher will be used to refer to students studying on a pre-service SLTE programme or who have recently completed one. Programme will be used to refer to the overall curriculum leading to a teaching qualification, and course will be used to describe a subject within a programme, e.g. Methodology.

iiThe original project also included institutions from Ukraine. However, only 14 questionnaire responses were obtained from Ukraine and almost half of the respondents taught in a university context. Therefore, responses have not been considered here

iiihttps://www.britishcouncil.uz/en/teach/reform-project

iv These were Age Appropriate Pedagogy, Course Design and Evaluation, Foreign Language Teaching Methodology, Technology and Language Teaching. 